\title{
Ice-front change and iceberg behaviour along Oates and George V Coasts, Antarctica, 1912-96
}

\author{
Massimo Frezzotti ${ }^{1}$ Alessandro Cimbelli, ${ }^{1}$ Jane G. Ferrigno ${ }^{2}$ \\ ${ }^{1}$ ENEA-AMB, Cr Casaccia, P.O. Box 2400, I-00100 Rome AD, Italy \\ ${ }^{2}$ United States Geological Survey, 955 National Center, Reston, VA 22092, U.S.A.
}

\begin{abstract}
Ice-front change may well be a sensitive indicator of regional climate change. We have studied the western Oates Coast from Cape Kinsey $\left(158^{\circ} 50^{\prime} \mathrm{E}, 69^{\circ} 19^{\prime} \mathrm{S}\right)$ to Cape Hudson $\left(153^{\circ} 45^{\prime} \mathrm{E}, 68^{\circ} 20^{\prime} \mathrm{S}\right.$ ) and the entire George V Coast, from Cape Hudson to Point Alden $\left(142^{\circ} 02^{\prime} \mathrm{E}, 66^{\circ} 48^{\prime} \mathrm{S}\right)$. The glaciers here drain part of the Dome Charlie and Talos Dome areas $\left(640000 \mathrm{~km}^{2}\right)$. A comparison between various documents, dated several years apart, has allowed an estimate of the surficial ice discharge, the ice-front fluctuation and the iceberg-calving flux during the last 50 years. The ice-front discharge of the studied coast has been estimated at about $90 \pm 12 \mathrm{~km}^{3} \mathrm{a}^{-1}$ in $1989-91,8.5 \mathrm{~km}^{3} \mathrm{a}^{-1}$ for western Oates Coast and $82 \mathrm{~km}^{3} \mathrm{a}^{-1}$ for George V Coast. From 1962-63 to 1973-74 the floating glaciers underwent a net reduction that continued from 1973-74 to 1989-91. On the other hand, from 1989-91 to 1996 the area of floating glaciers increased. Ninnis Glacier Tongue and the western part of Cook Ice Shelf underwent a significant retreat after 1980 and 1947, respectively. Satellite-image analysis of large icebergs has provided information about ice-ocean interaction and the existence of an "iceberg trap" along George V Coast. A first estimate of the mass balance of the drainage basin of Mertz and Ninnis Glaciers shows a value close to zero or slightly negative.
\end{abstract}

\section{INTRODUCTION}

The effects of global climate change may prove to be more pronounced in Antarctica than at mid-latitudes (Weller, 1993). Floating glaciers (ice shelves, ice tongues and glacier tongues) are sensitive to atmospheric warming, as shown by the break-up of ice shelves around the Antarctic Peninsula (Doake and Vaughan, 1991; Skvarca, 1994; Vaughan and Doake, 1996; Rott and others, 1996). Vaughan and Doake (1996) and Frezzotti (1997) pointed out that the extent of floating glaciers may well be a sensitive indicator of regional climate change. Much uncertainty about iceberg-calving processes makes it difficult to determine the present icesheet mass balance (Jacobs and others, 1992).

The Oates Coast is located between Cape Williams $\left(164^{\circ} 09^{\prime} \mathrm{E}, 70^{\circ} 30^{\prime} \mathrm{S}\right)$ and Cape Hudson $\left(153^{\circ} 45^{\prime} \mathrm{E}, 68^{\circ} 20^{\prime} \mathrm{S}\right)$ and the George V Coast between Cape Hudson and Point Alden $\left(142^{\circ} 02^{\prime} \mathrm{E}, 66^{\circ} 48^{\prime} \mathrm{S}\right)$. In a previous paper, Frezzotti (1997) studied the eastern part of Oates Coast between Cape Williams and Cape Kinsey $\left(158^{\circ} 50^{\prime} \mathrm{E}, 69^{\circ} 19^{\prime} \mathrm{S}\right)$; in this paper, the western part of Oates Coast, between Cape Kinsey and Cape Hudson, and the entire George V Coast have been studied. The study area is approximately $1400 \mathrm{~km}$ long. The ice shelves and glacier tongues here are fed by glaciers draining part of the Dome Charlie and Talos Dome areas $\left(640000 \mathrm{~km}^{2}\right)$. Bentley and Giovinetto (1991) pointed out that no mass-balance assessments of the East Antarctic ice sheet section that drains along Oates and GeorgeV Coasts have been made. Here we present a description of coastline change since 1912 and, as a step towards reducing the uncertainties about mass balance, we have attempted to evaluate the average area of iceberg calving each year (iceberg-calv- ing flux) and the volume of ice discharged at the ice front (icefront discharge volume) in 1989-91. Satellite-image analysis of large icebergs can provide useful information about iceberg behaviour, ocean currents and ice-ocean interaction. A first estimate of the mass balance of the drainage basin of Mertz and Ninnis Glaciers has been made.

\section{MATERIALS, METHODS AND DATA}

\section{Previous work}

Various authors (e.g. Ferrigno and Gould, 1987; Ferrigno and others, 1993; Lucchitta and others, 1993; Skvarca, 1994; Frezzotti and Mabin, 1994; Vaughan and Doake, 1996; Frezzotti, 1997) have shown that reliable records of ice-front changes and the velocity of floating glaciers can be obtained by analysis and comparison of different sources (historical maps and records, aerial photographs, satellite images) documenting conditions over several years.

The eastern part of Oates Coast was discovered during the 1910-13 Scott expedition. Maps drawn then do not allow accurate identification or mapping of floating glaciers. George V Coast was explored and mapped by members of the Australasian Antarctic Expedition (1911-14) under Sir Douglas Mawson (Mawson, 1914). However, the available material provides only a general outline of the Mertz and Ninnis Glacier Tongues observed at those times. Aerial photographs of Oates and George V Coasts were taken by the U.S. Navy and Australian National Antarctic Research Expedition (ANARE) using the trimetrogon aerial camera system (TMA) between 1947 and 1962. These photographs were used by the Australian Division of National Mapping 
Table 1. Areas of floating glaciers, western Oates Coast, 1947-96, shadow ice-thickness data average (IT) and surficial ice discharge at ice front ( SID)

\begin{tabular}{|c|c|c|c|c|c|c|c|c|c|c|c|}
\hline \multirow{3}{*}{ No. } & \multirow[t]{3}{*}{ Floating glaciers } & \multirow[t]{2}{*}{ Long. } & \multirow[t]{2}{*}{ Lat. } & \multirow[t]{2}{*}{$I T$} & \multirow[t]{2}{*}{$S I D$} & \multicolumn{6}{|c|}{ Floating ice area } \\
\hline & & & & & & $\begin{array}{l}1947^{a} \\
1959^{b}\end{array}$ & $\begin{array}{l}1962^{c} \\
1963^{d}\end{array}$ & $1973^{e}$ & $1980^{f}$ & $\begin{array}{c}1989^{g} \\
1991^{h}\end{array}$ & $1996^{j}$ \\
\hline & & E & $\mathrm{S}$ & $\mathrm{m}$ & $\mathrm{km}^{2} \mathrm{a}^{-1}$ & $\mathrm{~km}^{2}$ & $\mathrm{~km}^{2}$ & $\mathrm{~km}^{2}$ & $\mathrm{~km}^{2}$ & $\mathrm{~km}^{2}$ & $\mathrm{~km}^{2}$ \\
\hline 1 & glaciers & $158^{\circ} 30^{\prime}$ & $69^{\circ} 20^{\prime}$ & - & $0.6 \pm 0.2$ & - & $21.5^{c}$ & 22.3 & 21.3 & $24.9^{\mathrm{g}}$ & 26.4 \\
\hline 2 & glacier & $158^{\circ} 06^{\prime}$ & $69^{\circ} 12^{\prime}$ & - & $0.2 \pm 0.1$ & - & $9.5^{c}$ & 8.3 & 9.2 & 8 & 7.7 \\
\hline 3 & Matusevich Glacier Tongue & $157^{\circ} 16^{\prime}$ & $69^{\circ} 07^{\prime}$ & 270 & $10.0 \pm 0.3$ & $353^{\mathrm{b}}$ & $373^{\mathrm{c}}$ & 400 & 479 & $267^{\mathrm{g}}$ & 315.8 \\
\hline 4 & glacier tongue & $156^{\circ} 53^{\prime}$ & $69^{\circ} 09^{\prime}$ & 295 & $0.5 \pm 0.2$ & - & $42^{c}$ & 48 & 39 & $40.5^{g}$ & 39.3 \\
\hline 5 & ice shelf & $156^{\circ} 15^{\prime}$ & $69^{\circ} 03^{\prime}$ & 365 & $11.4 \pm 1.1$ & - & $466^{c}$ & 591 & - & $510^{\mathrm{h}}$ & 530 \\
\hline 6 & glacier & $155^{\circ} 27 \prime$ & $68^{\circ} 57^{\prime}$ & 410 & $0.5 \pm 0.2$ & - & $42^{\mathrm{d}}$ & 47.5 & - & $44^{\mathrm{h}}$ & 54 \\
\hline \multirow[t]{2}{*}{7} & Slava Ice Shelf & $154^{\circ} 51^{\prime}$ & $68^{\circ} 43^{\prime}$ & 400 & $3.0 \pm 0.6$ & $190^{a}$ & $307^{\mathrm{d}}$ & 280 & - & $336^{\mathrm{k}}$ & 351 \\
\hline & Western Oates Coast & Total & & & $26.2 \pm 3$ & - & 1261 & 1397 & - & 1230 & 1324 \\
\hline
\end{tabular}

For locations see Figure 1. Areas of floating glaciers were calculated using various dated ice-front positions but the same grounding line. a, b, c, Australian sketch map (1:1000 000); d, Argon photo; e, Landsat 1 MSS; f, Landsat 3 RBV; g, h, Landsat 4-5 TM; j, ERS 1 SAR; k, hypothesized.

to compile 1:1000000 scale sketch maps of the area. The Soviet Antarctic Expedition mapped the ice-front position of Mertz and Ninnis Glacier Tongues during February 1958 (Bardin, 1964; Koblents, 1965) using aerial photographs; moreover Koblents (1965) reported the ice-front position mapped by an aerial survey of the French Antarctic Expedition of Mertz Glacier Tongue in 1952. During the U.S. Deep Freeze 79 expedition, a new map of the Mertz and Ninnis Glacier Tongues was drawn using ship's radar (Anderson and others, 1979). Wendler and others (1996) used Japanese SAR JERS-1 satellite images, acquired in 1993 and 1994, to study Mertz and Ninnis Glacier Tongues.

\section{Methodology}

In this study, we have integrated the previous data with satellite images and photos acquired by Argon (1963), Landsat 1
MSS (1973-74), Landsat TM 4 and 5 (1989-91), ERS 1-2 SAR (1996) of the entire Oates and George V Coasts, a Landsat 3 RBV image (1980) for a part of Oates Coast and a Soyuz Kosmos KATE 200 image (1984) for the western part of George V Coast. Digital data were used when available but were not available for Argon, Soyuz Kosmos KATE 200, Landsat 3 RBV and some Landsat 1 MSS images, therefore the photographic products were scanned from $50 \mu \mathrm{m}$ to $200 \mu \mathrm{m}$ to obtain a digital dataset.

Satellite-image maps with a spatial resolution of $30 \mathrm{mpixel}^{-1}$ were created using Landsat TM images. Images were georeferenced by means of geographical coordinates of satellite-image corners. Georeferencing was carried out by rectifying the images in a Polar Stereographic projection, using a linear conversion matrix. Using these georeferenced TM satellite images as a reference, other

Table 2. Areas of floating glaciers, George V Coast, 1912-96, shadow ice-thickness data average (IT) and surficial ice discharge at ice front (SID)

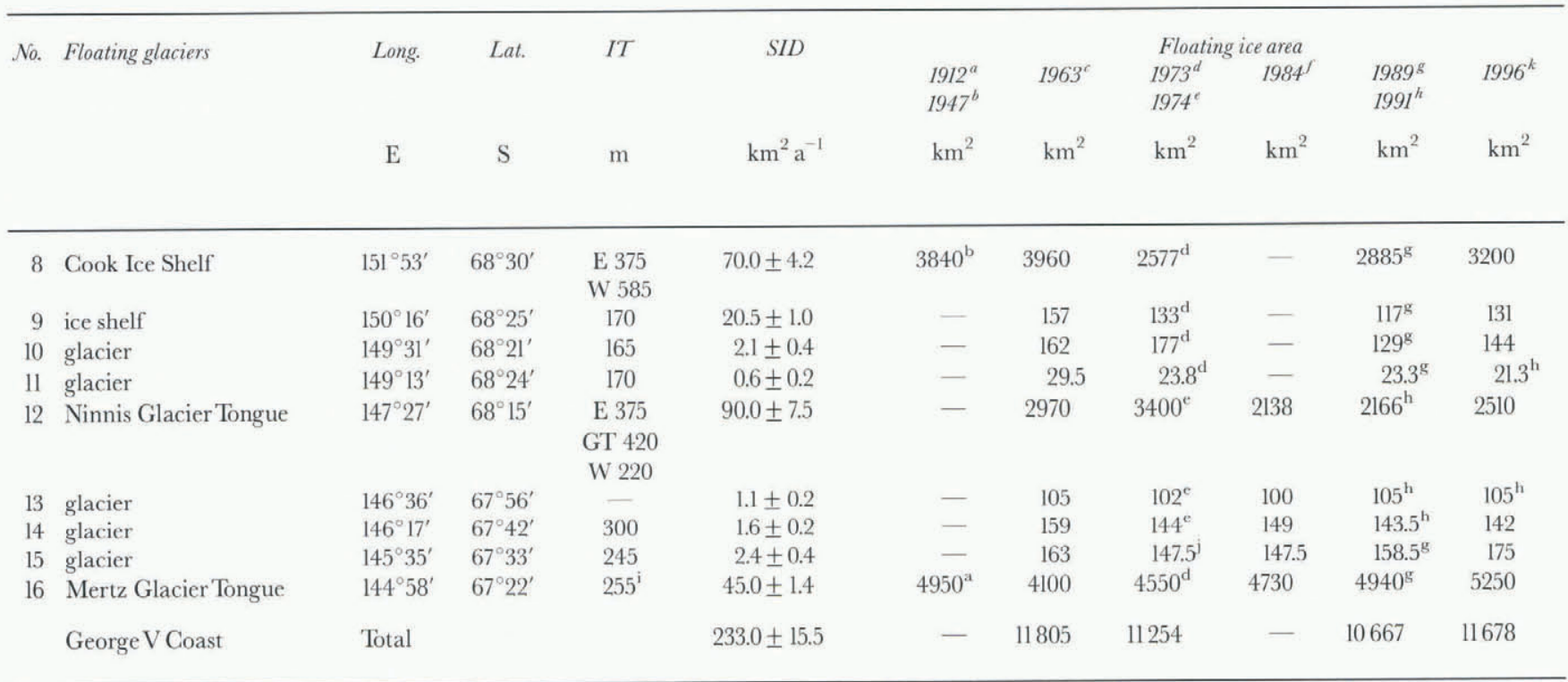

For locations see Figures 2 and 3. Areas of floating glaciers were calculated using various dated ice-front positions but the same grounding line. Data sources used: a, Mawson (1914); b, Australian sketch map (1:1000 000); c, Argon photo; d, e, Landsat 1 MSS; f, Soyuz Kosmos Kate; g, h, Landsat 4-5 T M; i, Wendler and others (1996); j, hypothesized; k, ERS1-2 SAR;GT, glacier tongue; E, eastern part; W, western part. 
satellite images and photos (Argon, Landsat 1 MSS, Landsat 3 RBV, Soyuz Kosmos KATE 200 and ERS1-2 SAR) were rectified by identifying about 10-15 tiepoints for each image pair and using a linear conversion matrix giving an rms error ranging from 1-3 pixels.

The available maps have considerable and largely unknown inaccuracies. These have been corrected where possible through reference to the satellite-derived data and only the data that are in agreement with satellite-image data and glaciological features (ice flow, ice velocity, ice-front change etc.) have been used. The satellite images and maps of floating glaciers were analysed, compared and organized into a geographic information system (GIS) using ERDAS and ARCINFO software (Tables 1 and 2). The geographical positions of glacial features (ice fronts, snowdrifts, sastrugi, drift plumes, crevasses, etc.) in different years made it possible to determine the surface velocities and positional variations of the ice fronts.

Landsat TM satellite images were acquired (21 Feb 1989, 17 Feb 1991, 3 Mar 1989 and 15 Mar 1991) with low Sun-elevation angles (respectively $20^{\circ}, 20^{\circ}, 18^{\circ}$ and $13^{\circ}$ above the horizon). By measuring the length of the shadows, we used the known Sun elevation to calculate the freeboard of icebergs and glacier tongues (Swithinbank, 1988). Applying the freeboard-thickness relationships of Shabtaie and Bentley (1982) and of Keys and Fowler (1989), developed for the Ross Ice Shelf and the icebergs grounded along the Victoria Land coast, we computed ice-front and iceberg thickness at 241 points to evaluate the iceberg-discharge volume, assuming a density of $1027.5 \mathrm{~kg} \mathrm{~m}^{-3}$ for sea water and $865 \mathrm{~kg} \mathrm{~m}^{-3}$ for floating ice. We estimated an error of 1 pixel $(28.5 \mathrm{~m})$ in the determination of shadow length and therefore an error in the determination of ice thickness between $42 \mathrm{~m}\left(13^{\circ}\right)$ and $65 \mathrm{~m}\left(20^{\circ}\right)$.

As a step towards reducing the uncertainties about the iceberg-calving rates, we attempted to evaluate the average area of iceberg calving each year (surficial flux) and, where ice thicknesses are available, the volume of ice discharged at the ice front during 1989-91. The surficial iceberg-calving flux was assessed on the basis of the annual surficial ice-front discharge of each floating glacier and the change in area of glacier tongues and ice shelves during the study period (surficial iceberg-calving flux $=$ surficial ice-front discharge change in floating glacier area ${ }^{-1}$ ). The surficial ice discharge was estimated at the floating ice front on the basis of the average velocity and of the width measured using satellite images. Frezzotti and others (1998) have evaluated the errors in measured average velocity through comparison of GPS data and satellite-image tracking data and have determined an error of satellite-tracking ice-velocity measurement of $\pm 15-70 \mathrm{~m} \mathrm{a}^{-1}$. We used the ice velocity at the ice front because of the longitudinal and transversal strain rate present in the floating part mainly where the tongue emerges from the fjord.

Ice-thicknesses of Ninnis and Mertz Glaciers have been obtained from airborne radio-echo sounding (RES) surveys by the Scott Polar Research Institute, the U.S. National Science Foundation and the Technical University of Denmark (Steed and Drewry, 1982; Drewry and Jordan, 1983). Inertial navigation systems were used for navigation; this technique presents errors which increase as navigation proceeds. Integration of data about ice thickness (airborne RES survey) and ice velocity (satellite-image tracking) presented many difficulties due mainly to lack of ground- control points for satellite-image rectification and navigational inconsistencies in the RES data. Therefore ice discharge at the grounding line, calculated on the basis of these data, is only a general estimate.

The drainage area of the Mertz and Ninnis Glacier basin has been calculated using a digital elevation model (DEM) derived by ERS 1 radar altimeter data (Brisset and Rémy, 1996).

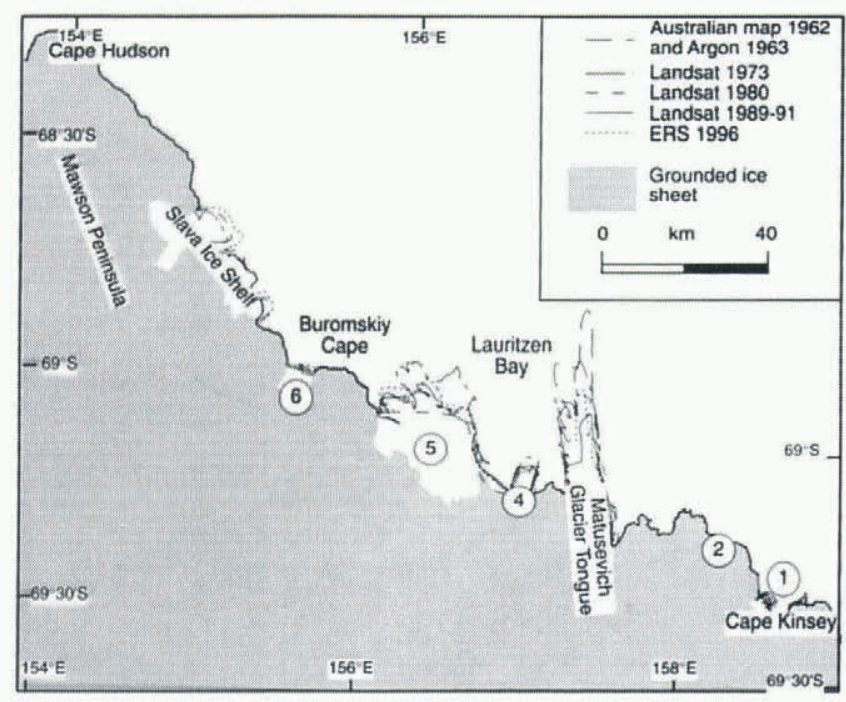

Fig. 1. Variations in the ice front, western Oates Coast. Numbers are used to identify unnamed features.

\section{DISCUSSION}

\section{Oates Coast}

The part of Oates Coast studied extends from Cape Kinsey to Cape Hudson (Fig. 1). The glaciers flowing in the central part, from Cape Kinsey to Buromskiy Cape $\left(155^{\circ} 27^{\prime} \mathrm{E}\right.$, $\left.68^{\circ} 57^{\prime} \mathrm{S}\right)$, drain the northwestern slope of Talos Dome, the extreme northeastern sector of the East Antarctic ice sheet. In the western coastal stretch, between Slava Ice Shelf and Cape Hudson, are the glaciers that drain the coastal areas of the Mawson Peninsula. The glaciers in these two sections of coast together drain an area of about $75000 \mathrm{~km}^{2}$. The area of the floating glaciers in 1996 was $1334 \mathrm{~km}^{2}$ (Table 1). The main glaciers here are Matusevich Glacier and those glaciers that feed the ice shelf (No. 5) flowing into Lauritzen Bay (Fig. 1). The surficial ice discharge of the floating glaciers that terminate at this part of the coast can be estimated at around $26 \pm 3 \mathrm{~km}^{2} \mathrm{a}^{-1}$, about $82 \%$ of which is from Matusevich Glacier $\left(10 \pm 0.3 \mathrm{~km}^{2} \mathrm{a}^{-1}\right)$ and ice shelf No. 5 $\left(11.4 \pm 1.1 \mathrm{~km}^{2} \mathrm{a}^{-1}\right)$. Using the surficial ice discharge and the ice thickness derived from the shadow satellite-image technique for each glacier, we estimated for 1989-91 an ice-front discharge volume of about $8.5 \pm 1.8 \mathrm{~km}^{2} \mathrm{a}^{-1}$ for western Oates Coast. Between 1962-63 and 1973, an increase of about $136 \mathrm{~km}^{2}$ of the area of floating glaciers occurred, with an average value of iceberg calving of $12 \mathrm{~km}^{2} \mathrm{a}^{-1}$. However, during the period from 1973 to 1989-91 there was a reduction in the area of floating glaciers of about $167 \mathrm{~km}^{2}$ with an average iceberg-calving value of $36 \mathrm{~km}^{2} \mathrm{a}^{-1}$. Between 1989-91 and 1996 we evaluated an increase of about $104 \mathrm{~km}^{2}$ with an average iceberg-calving value of $12 \mathrm{~km}^{2} \mathrm{a}^{-1}$. The major calving events for Matusevich Glacier Tongue occurred in 1947 

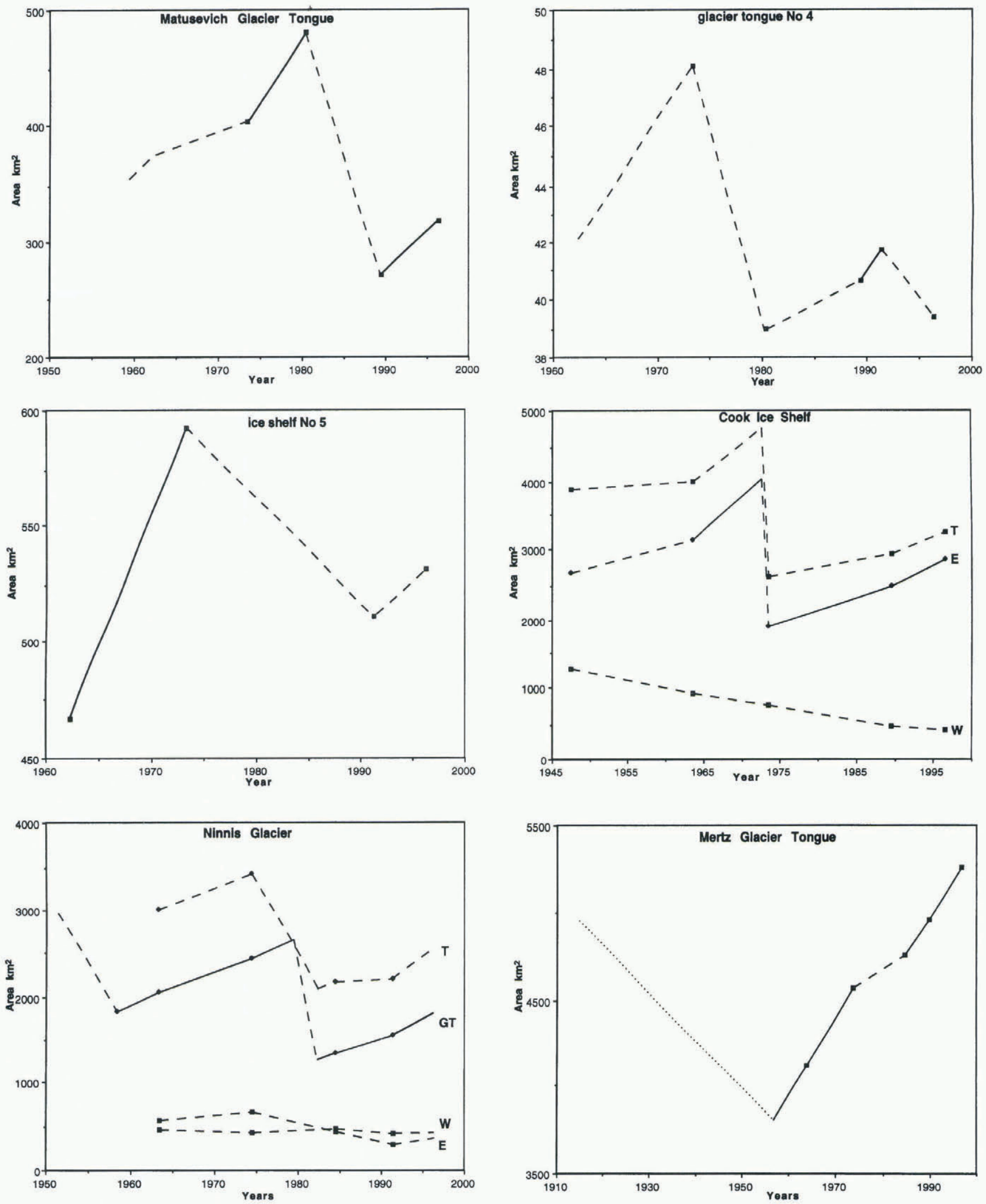

Fig. 2. Changes in the area of selected floating glaciers with time. Dotted line, uncertain variation; dashed line, variation with iceberg calving; solid line, increase in area without important iceberg calving. The floating part of Ninnis Glacier $(T)$ was divided into three parts due to its considerable size, complexity, and history: the western part (W), from Cape Webb to Cape Pollock; the central part (GT), from Cape Pollock to Cape Spencer; and the eastern part, from Cape Spencer to Organ Pipe Cliff $(E)$. Cook Ice Shelf $(T)$ was divide in two parts (eastern, $E$; western, $W$ ) due to different ice-front histories. Location of glaciers in Figures 1,3 and 4. 
and between 1980 and 1989 and for ice shelf No. 5 between 1973 and 1991 (Table 1 and Fig. 2).

\section{George V Coast}

The George V Coast drains the northeastern slope of Dome Charlie. The glaciers here drain an area of about $565000 \mathrm{~km}^{2}$, while the area of the floating glaciers was about $11678 \mathrm{~km}^{2}$ in 1996 (Table 2). Except for Mertz and Ninnis Glacier Tongues, these glaciers have floating parts within their fjords; none extend for any significant distance beyond the boundaries of the valley (Figs 3 and 4).

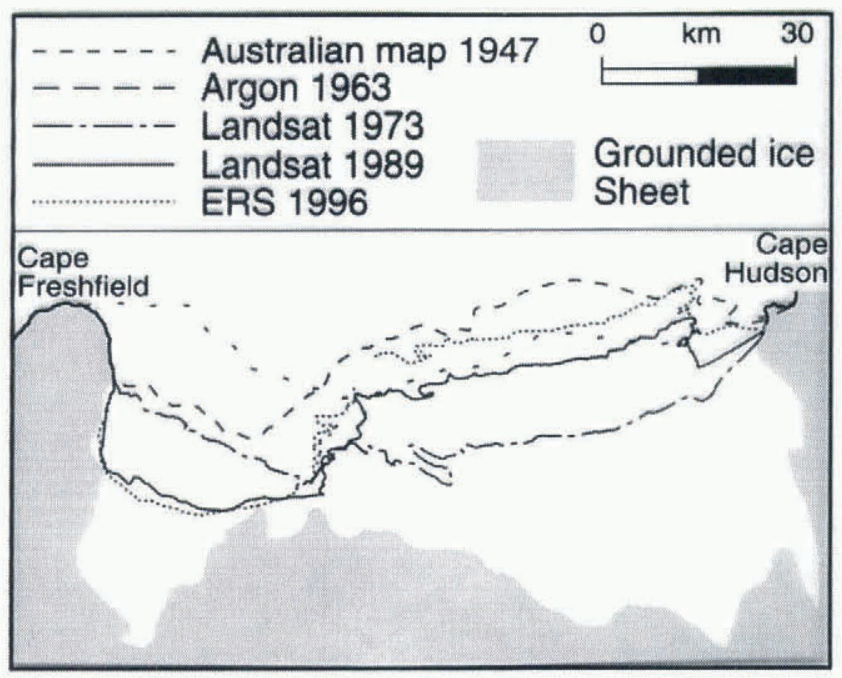

Fig. 3. Eastern George V Land showing Cook Ice Shelf and variations in the ice front.

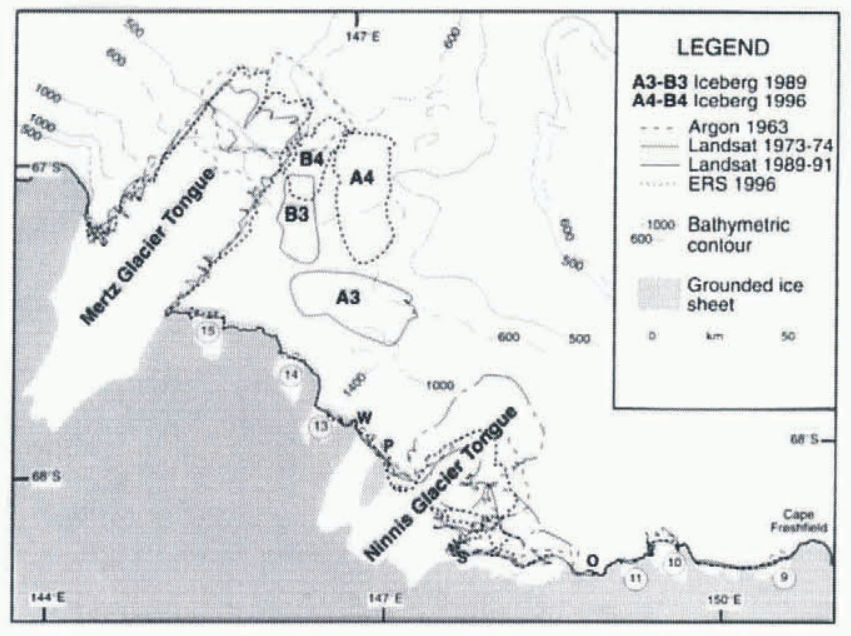

Fig. 4. Western George V Land showing variations in the ice front and movement of icebergs. Numbers are used to identify unnamed features. Bathymetric contours are based on Chase and others (1987). W, Cape Webb; P, Cape Pollock; S, Cape Spencer; O, Organ Pipe Cliffs.

\section{Analysis of iceberg behaviour}

In the Soyuz Kosmos KATE 200 image of the western part of George V Coast acquired in 1984 (Fig. 5) 6 large icebergs, ranging in size from $90-860 \mathrm{~km}^{2}$, may be observed. Analysis of Landsat 1 MSS 1974 satellite images showed that up to 5 of these icebergs (A, B, C, D, E) derive from Ninnis Glacier. Icebergs $\mathrm{A}, \mathrm{B}, \mathrm{C}$ and $\mathrm{D}$ represent the central section of the
Glacier Tongue while iceberg $\mathrm{E}$ is visible as part of the large iceberg that is about to calve from the coast east of Ninnis Glacier (Fig. 5). Further analysis of the 1974 images, and surveys carried out during the 1979 Deep Freeze expedition (Anderson and others, 1979), indicate that the calving event that created icebergs A, B, C, and D occurred between 1980 and 1982. Iceberg E must have broken off before 1979, since it is mapped between the Ninnis and Mertz Glacier Tongues by Anderson and others (1979).

The sixth iceberg ( $\mathrm{F}$ in Fig. 5), the largest $(41 \times 30 \mathrm{~km})$, derives from the eastern section of Cook Ice Shelf. Landsat 1 MSS 1973 images show a dramatic ice-front retreat compared to the position in 1963 (Figs. 2 and 3) which is related to calving of iceberg F. The area of iceberg F $\left(890 \mathrm{~km}^{2}\right)$ is compatible with the change in ice shelf area which was estimated for the eastern section of Cook Ice Shelf between 1963 and the early 1970s; moreover the detected iceberg morphologies (ice flow, crevasse pattern etc.) are compatible with those observed on the 1963 Argon photo. Therefore, the calving event occurred in the early 1970s; we can estimate an average $24 \mathrm{~km} \mathrm{a}^{-1}$ drift rate for iceberg $\mathrm{F}$ between 1972 and 1984 from the distance between Cook Ice Shelf and the ocean section in front of Ninnis Glacier Tongue.

Icebergs $\mathrm{A}$ and $\mathrm{B}$ were noted by Wendler and others (1996) in the 1993 JERS-1 images and were related by them to Ninnis Glacier Tongue. These icebergs are also visible in 1989-91 Landsat TM images and in the 1996 ERS I SAR image. The succession of images shows that these two icebergs have the same shape and size in 1984 and in 1996, about 15 years after their calving. Their drift rate may be estimated between 1984 and 1996 at $4-5 \mathrm{~km} \mathrm{a}^{-1}$, an extremely low drift rate for a floating iceberg. Many authors (e.g. Swithinbank and others, 1977; Tchernia and Jeannin, 1984; Keys and others, 1990) have pointed out that offshore iceberg movement in the Ross Sea ranges from $3-12 \mathrm{~km} \mathrm{~d}^{-1}$ and is strictly related to ocean and coastal currents and that icebergs tended to align their long axis parallel to the host currents. Ferrigno and others (1993) mention that the Thwaites Iceberg Tongue in the Walgreen Coast $\left(108^{\circ} \mathrm{W}\right.$, $74^{\circ} 30^{\prime} \mathrm{S}$ ) moved approximately $140 \mathrm{~km}$ towards the west (23 $\mathrm{km} \mathrm{a}^{-1}$ between 1986 and 1992). The very low velocity of icebergs A and B suggest that they are grounded, but bathymetric maps (Fig. 4) by Chase and others (1987) indicate that the bottom topography between Mertz and Ninnis Glacier Tongues is dominated by a linear inner-shelf depression deep parallel to the coast. This depression reaches depths of over 1400 m just west of the Ninnis Glacier Tongue, where iceberg A was present in 1984 and 1989-91 images. On the basis of the shadows of these icebergs shown in 1989 and 1991 images, their average thicknesses may be estimated to be $240 \mathrm{~m}$ ( 23 points, $\min .135 \pm 42 \mathrm{~m}$, max. $370 \pm 42 \mathrm{~m}$ ) for iceberg $\mathrm{A}$ and $230 \mathrm{~m}$ (12 points, min. $190 \pm 42 \mathrm{~m}$, max. $270 \pm 42 \mathrm{~m}$ ) for iceberg B. Floating ice of such thicknesses require $110-310 \mathrm{~m}$ water depth, much less than the depth of the ocean (from 1400-500 $\mathrm{m}$ ) in which they are shown in satellite images taken from 1984-96. The observed drift of icebergs in the area is towards the west (Domack and Anderson, 1983) or northwest (Keys, 1990). Moreover Barnes (1987) concludes that the drift directions of icebergs offshore George V Coast is southeast-northwest and in front of Mertz Glacier Tongue south-southwest-north-northeast on the basis of sea-bed morphology that may be related to modern iceberg keels.

Bardin (1964) pointed out that in February 1958 two 


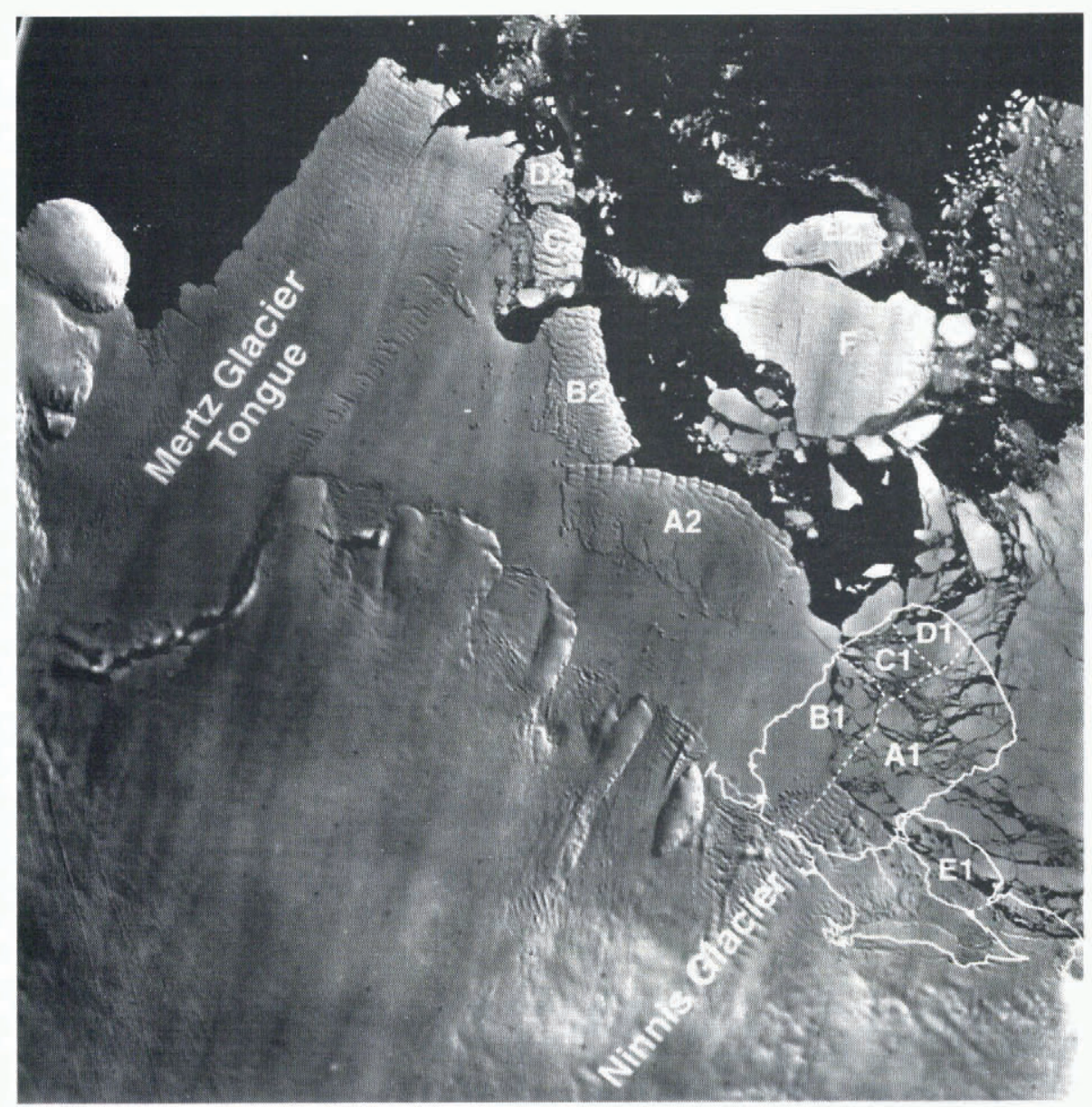

Fig. 5. Soyuz Kosmos KATE 200 image of 14 February 1984 showing the western part of George V Coast. Solid line, Ninnis Glacier ice front in 1974; dashed line, iceberg limit; A1, B1, C1, D1, E1 are iceberg positions in 1974 before calving; A2, B2, C2, D2, E2 are icebergs derived from Ninnis Glacier in 1984; F, iceberg calved during 1972-73 from Cook Ice Shelf in 1984.

large icebergs $(46 \times 18 \mathrm{~km}$ and $68 \times 18 \mathrm{~km})$ were situated close to Ninnis Glacier Tongue and that Soviet aerial photographs showed a sharp difference in morphology between Ninnis Glacier Tongue and the icebergs. He concluded from the difference that the icebergs were produced by another glacier. Another large iceberg in front of Mertz Glacier Tongue was observed in U.S NavyTMA aerial photographs of 1956, was mapped by the Soviet expedition during 1958 (Bardin, 1964) and is visible on an Argon photo of 1963 (Fig. 4). Analysis of the Argon photograph made it possible to determine that this iceberg $\left(1480 \mathrm{~km}^{2}, 55 \times 37 \mathrm{~km}\right)$ derives from Ninnis Glacier Tongue and not from Mertz Glacier Tongue as hypothesized by Bardin (1964). The persistence of floating icebergs along George V Coast leads us to hypothesize the existence of an "iceberg trap" that is related to the stopping effect caused by Mertz Glacier Tongue and to the extremely low velocity of coastal currents along this stretch of coast. On the basis of the drift of icebergs we may determine that the currents in the first 100 $300 \mathrm{~m}$ (iceberg draught) depth are along the coast with an east-west direction from Cape Hudson to Mertz Glacier Tongue and with a southwest-northeast direction from Mertz Glacier Tongue to the continental slope, directions in agreement with previous authors and with very low velocities from $5-24 \mathrm{~km} \mathrm{a}^{-1}$.

Comparison between thicknesses $(430 \mathrm{~m})$ of Ninnis Glacier Tongue in 1989 (55 points, $\min .310 \mathrm{~m}$, max. $756 \mathrm{~m}$ ) and of the icebergs that originated from it in 1980-82 (icebergs A $240 \mathrm{~m}$ and B $230 \mathrm{~m}$ ), suggest a basal melting rate of about $12 \mathrm{~m} \mathrm{a}^{-1}$ between 1973 and 1989, a value similar to the one determined at the calving front of Pine Island Glacier along the Walgreen Coast (Jacobs and others, 1996) and correlated to relatively warmer water (Circumpolar Deep Water). Jacobs (1989) has hypothesized that basal melting of Mertz Glacier Tongue exceeds $7 \mathrm{maa}^{-1}$; moreover, he pointed out an intrusion of "warm" water derived from Circumpolar Deep Water along George V Coast. Oceanic circulation conditions (iceberg drift and basal melting) and the "iceberg trap" of Walgreen and George V Coast seem very similar in spite of the considerable distance between them, while they seem totally different from the conditions near Oates-Pennell Coasts and in the Ross Sea.

\section{Ice-front fluctuation}

Many authors have described ice-front variations of the Mertz and Ninnis Glacier Tongues (Bardin, 1964; Koblents, 1965; Domack and Anderson, 1983; Holdsworth, 1985; Wendler and others, 1996) using data derived from cartography of the Mawson (1911-14), Soviet (1958) and U.S.A. (1979) expeditions. If one supposes a steady-state condition for ice velocity and flow, the integration and comparison of all these data with data from the most recent satellite images, and Argon photos, present many incongruities. In particular, the following were determined:

Mawson's (1914) cartography of Mertz Glacier Tongue based on surveys on the fast ice and on the ship Aurora seems rather accurate, whereas Ninnis Glacier Tongue surveys, carried out only by the "eastern coastal party" 
present many uncertainties, as already pointed out by Holdsworth (1985) and Bardin (1964). The extremely irregular ice front of Ninnis Glacier Tongue in 1912, as mapped by Mawson, would seem to indicate the possibility that it represents the ice front of the Glacier Tongue plus one or more icebergs in contact with the main Glacier Tongue.

Koblents' (1965) report on the 1952 ice-front morphology of Mertz Glacier Tongue, determined by French survey. The ice-front shape is anomalous with respect to the glacier-tongue history during this century determined from other sources and these data contradict those reported by the same authors for the year 1958 .

Analysis of the Argon photo of 1963 showed that the 1962 ice-front position of Mertz Glacier Tongue, as mapped in the Australian 1:1000 000 scale sketch maps, represents the ice front of the glacier tongue plus the iceberg observed from U.S. Navy TMA air photo in contact with the main glacier tongue since 1956.

Wendler and others (1996) report an area of $8100 \mathrm{~km}^{2}$ for Mertz Glacier Tongue in 1993. Since the glacier-tongue width is about $38-40 \mathrm{~km}$, a length of $200-210 \mathrm{~km}$ would be necessary to yield an area of $8100 \mathrm{~km}^{2}$; such a length is not compatible (Table 2) with the length determined by 1989 Landsat TM $(100 \mathrm{~km})$ and 1996 ERS l satellite images $(108 \mathrm{~km})$ or with the JERS 1 image reported by the same authors. Wendler and others (1996) further hypothesize a grounding line at the coastline, while on the basis of the satellite images it may be located about $50 \mathrm{~km}$ within the fjord-like valley. The same groundingline location, $50 \mathrm{~km}$ within the fjord-like valley, is hypothesized by BAS and others (1993).

Wendler and others (1996) have observed an extraordinary retreat of Ninnis Glacier Tongue since 1912; the authors pointed out that the reduction to about onethird of the 1913 size occurred during the earlier part of this century. Our studies suggest that the retreat has been more pronounced from the 1980s forward, since we believe that the Ninnis Glacier Tongue extension during 1913 was similar to the one in 1973 and that the remaining mapped area was icebergs.

\section{Iceberg-calving flux}

We estimate a surficial ice discharge of the floating glaciers that terminate at this part of coast of around $233 \pm 16 \mathrm{~km}^{2} \mathrm{a}^{-1}$ (Table 2), of which $88 \%$ comes from Mertz Glacier Tongue $\left(45 \pm 1.4 \mathrm{~km}^{2} \mathrm{a}^{-1}\right)$, Ninnis Glacier Tongue $\left(90 \pm 7.5 \mathrm{~km}^{2} \mathrm{a}^{-1}\right)$ and the Cook Ice Shelf $\left(70 \pm 4.2 \mathrm{~km}^{2} \mathrm{a}^{-1}\right)$. Using the surficial-ice discharge and the ice thickness derived from the shadow satellite-image technique (Table 2), we have estimated the ice-front discharge volume of George V Coast to be about $82 \pm 11 \mathrm{~km}^{3} \mathrm{a}^{-1}$ in 1989-91. During the period between 1963 and $1973-74$ a decrease of about $550 \mathrm{~km}^{2}$ of the area of floating glaciers occurred with an average value of iceberg calving of about $292 \mathrm{~km}^{2} \mathrm{a}^{-1}$. The area of floating glaciers continued to decrease during the period from 1973-74 to $1989-91$ with a reduction in area of about $587 \mathrm{~km}^{2}$ and an annual value of iceberg calving of $368 \mathrm{~km}^{2} \mathrm{a}^{-1}$. In contrast, during the period from 1989-91 to 1996, there was an increase in the area of floating glaciers of about $1011 \mathrm{~km}^{2}$ with an average value of iceberg calving of $70 \mathrm{~km}^{2} \mathrm{a}^{-1}$.

\section{Calving events - past and future}

The major calving event for Cook Ice Shelf (about $1200 \mathrm{~km}^{2}$ ) occurred before 1973 in the eastern part. Subsequently, the satellite images have shown constant growth of the eastern part of the ice shelf, with no substantial iceberg calving (Figs 2 and 3). On the other hand, in the western part we have observed a continuous and significant retreat since 1947, with a total ice-front retreat greater than $30 \mathrm{~km}$ (Fig. 2). The major calving events for Ninnis Glacier Tongue occurred during the early 1950 s with iceberg calving $>1480 \mathrm{~km}^{2}$, and between 1980 and 1982 with the calving of icebergs A, B, C and D (about $1450 \mathrm{~km}^{2}$ ); subsequently the satellite images have revealed a general growth. A 1996 ERS satellite image shows that a calving event of about $700 \mathrm{~km}^{2}$ will occur in the near future from the glacier tongue. This calving event will cause the projecting glacier tongue to break off and the ice front to retreat within the fjord-like valley.

We have reconstructed the evolution of Mertz Glacier Tongue during most of the 20th century (Figs 2 and 4). The glacier tongue was about $150 \mathrm{~km}$ long (from the grounding line) in 1912. During 1958, the length of the glacier tongue was about $113 \mathrm{~km}$. Subsequently, satellite images have evidenced a constant growth of the glacier tongue, with no substantial iceberg calving, reaching a length of $155 \mathrm{~km}$ in February 1996, an average advance of $1 \mathrm{~km} \mathrm{a}^{-1}$. On the basis of this reconstruction we may hypothesize at least one or two important calving events between 1912 and 1956, with an estimated ice loss $>3000 \mathrm{~km}^{2}$.

\section{Significant retreat}

Most of the floating glaciers have shown cyclic behaviour without a strong trend. Exceptions to this general style are the western parts of Cook Ice Shelf and Ninnis Glacier Tongue, which have undergone a significant retreat at least since 1947 and 1980, respectively. These floating glaciers are characterized by numerous linear snow-filled depressions and rifts that extend across the floating glacier a few kilometres downstream of the grounding line. These are interpreted as the surface expression of bottom crevasses. The depressions become accentuated from the generation point to the ice front and are the preferential line of major rift formation and subsequently of calving. Increased melting along bottom crevasses might reduce the strength of the floating glacier and cause an increased calving flux. Comparison of ice thicknesses ( $\min .855 \mathrm{~m}$, max. $1243 \mathrm{~m}$ ) collected using RES in 1974-75 (Steed and Drewry, 1982) with thicknesses ( $\min .310 \mathrm{~m}$, max. $750 \mathrm{~m}$ ) estimated from shadows on the 1989 satellite image seems to indicate a sharp thinning of the ice in the floating section of Ninnis Glacier. The constant reduction in the areas of these two floating glaciers in the last 20 years and possible thinning may be linked to an increase in the melting rate because of changes in ice-ocean interaction, as noted for the floating glaciers of the Cape Adare area (Frezzotti, 1997).

\section{Mass balance}

By combining RES ice-thickness and ice-velocity values close to the grounding line, it has been possible to estimate the ice-discharge values at about $62 \mathrm{Gta}^{-1}$ for Mertz and Ninnis Glaciers. Using a DEM constructed from radar altimeter data (Brisset and Rémy, 1996), we have estimated the size of the drainage basin of these two glaciers to be $420000 \mathrm{~km}^{2}$. According to Giovinetto and Bentley (1985), the surface net accumulation value on grounded ice in this 
area is $138 \mathrm{~kg} \mathrm{~m}^{-2} \mathrm{a}^{-1}$. Using this value we have estimated the snow and ice accumulated over the drainage area to be $58 \mathrm{Gta}^{-1}$. The large uncertainty in the numerous parameters taken into consideration makes it difficult to determine the value of the mass balance in this area in quantitative terms, but we believe that the mass balance is close to zero or slightly negative.

\section{ACKNOWLEDGEMENTS}

Research was carried out within the framework of a Project on Glaciology and Paleoclimatology of the Programma Nazionale di Ricerche in Antartide, and was supported financially by Ente Nazionale Energia e Ambiente through a co-operation agreement with Università degli Studi di Milano, and by the European Union under grants ENV4CT95-0124. At the U.S. Geological Survey, research and data purchase were funded by the Global Change and Climate History Program. The Landsat TM images of Antarctica's coastal regions were obtained through a programme sponsored by an international consortium of nations belonging to the Scientific Committee on Antarctic Research (SCAR) Working Group on Glaciology. The ERS images were made available at research cost by the European Space Agency.

Thanks are due to D. G. Vaughan for providing the RES data and F. Rémy for providing DEM data. C. S. M. Doake, C. R. Bentley and an anonymous reviewer provided helpful comments for improving the manuscript.

\section{REFERENGES}

Anderson, J. B., K. Balshaw, E. Domack, D. Kurtz, R. Milan and R. Wright. 1979. Geological survey of East Antarctic continental margin aboard USCGC Glacier. Antart. 7. U.S., 14(5), 142-144.

Bardin, V.I. 1964. A fresh view of the nature of Ninnis Glacier tongue. Sov. Antarct. Exped. Inf. Bull., 2, 308-311.

Barnes, P.W. 1987. Morphologic studies of the Wilkes Land continental shelf, Antarctica: glacial and iceberg effects. In Eittreim, S. L. and M. A. Hampton, eds. The Antartic continental margin: geology and geophysics of offshore Wilkes Land. Houston, TX, Circum-Pacific Concilium for Energy and Mineral Resources, 175-193. (CPCEMR Earth Science Series 5a.)

Bentley, C. R. and M. B. Giovinetto. 1991. Mass balance of Antarctica and sea level change. In Weller, G., C. L. Wilson and B. A. B. Severin, eds. International Conference on the Role of the Polar Regions in Global Change: proceedings of a conference held June 11-15, 1990 at the University of Alaska Fairbanks. Vol. II. Fairbanks, AK, University of Alaska. Geophysical Institute/Center for Global Change and Arctic System Research, 481-488.

Brisset, L. and F. Rémy. 1996. Antarctic topography and kilometre-scale roughness derived from ERS-1 altimetry. Ann. Glaciol., 23, 374-381.

British Antarctic Survey (BAS), Scott Polar Research Institute (SPRI) and World Conservation Monitoring Centre (WCMC). 1993. Antarctic digital database user's guide and reference manual. Cambridge, Scientific Committee on Antarctic Research.

Chase, T. E., B. A. Seeking, J. D. Young and S. L. Eittreim. 1987. Marine topography of offshore Antarctica. In Eittreim, S. L. and M. A. Hampton, eds. The Antarctic continental margin: geology and geophysics of offshore Wilkes Land. Houston, TX, Circum-Pacific Concilium for Energy and Mineral Resources, 147. (CPCEMR Earth Science Series 5a.)

Doake, C. S. M. and D. G. Vaughan. 1991. Rapid disintegration of the Wordie Ice Shelf in response to atmospheric warming. Nature, $350(6316), 328-330$.
Domack, E.W. and J. B. Anderson. 1983. Marine geology of the George V continental margin: combined results of the Deep Freeze 79 and the 1911-1914 Australian expedition. In Oliver, R. L., P. R. James and J. B. Jago, eds. Antarctic earth science. Cambridge, etc., Cambridge University Press. Australian Academy of Science, 402-406.

Drewry, D. J. and J. R. Jordan. 1983. The bedrock surface of Antarctica. In Drewry, D. J., ed. Antarctica: glaciological and geophysical folio. Cambridge, University of Cambridge. Scott Polar Research Institute, Sheet 3.

Ferrigno, J. G. and W. G. Gould. 1987. Substantial changes in the coastline of Antarctica revealed by satellite imagery. Polar Rec., 23(146), 577-583.

Ferrigno, J. G., B. K. Lucchitta, K. F. Mullins, A. L. Allison, R. J. Allen and W. G. Gould. 1993. Velocity measurements and changes in position of Thwaites Glacier/iceberg tongue from aerial photography, Landsat images and NOAA AVHRR data. Ann. Glaciol., 17, 239-244.

Frezzotti, M. 1997. Ice front fluctuation, iceberg calving flux and mass balance of Victoria Land glaciers. Antarct. Sci., 9(1), 61-73.

Frezzotti, M. and M. C. G. Mabin. 1994. 20th century behaviour of Drygalski Ice Tongue, Ross Sea, Antarctica. Ann. Glaciol, 20,397-400.

Frezzotti, M., A. Capra and L. Vittuari. 1998. Comparison between glacier ice velocities inferred from GPS and sequential satellite images. Ann. Glaciol., 27 (see paper in this volume).

Giovinetto, M. B. and C. R. Bentley. 1985. Surface balance in ice drainage systems of Antarctica. Antarct. J. U.S., 20 (4), 6-13.

Holdsworth, G. 1985. Some effects of ocean currents and wave motion on the dynamics of floating glacier tongues. In Jacobs, S. S., ed. Oceanology of the Antarctic continental shelf. Washington, DC, American Geophysical Union, 253-271. (Antarctic Research Series 43.)

Jacobs, S. S. 1989. Marine controls on modern sedimentation on the Antarctica continental shelf. Mar. Geol., 85 (2-4), 121-153.

Jacobs, S. S., H. H. Hellmer, C. S. M. Doake, A. Jenkins and R. M. Frolich. 1992. Melting of ice shelves and the mass balance of Antarctica. F. Glaciol., 38(130), 375-387.

Jacobs, S. S., H. H. Hellmer and A. Jenkins. 1996. Antarctic ice sheet melting in the southeast Pacific. Geophys. Res. Lett., 23 (9), 957-960.

Keys, J. R. 1990. Ice. In Glasby, G. P., ed. Antarctic sector of the Pacific. Amsterdam, Elsevier, 95-123. (Oceanography Series 51.)

Keys, H. and D. Fowler. 1989. Sources and movement of icebergs in the south-west Ross Sea, Antarctica. Ann. Glaciol., 12, 85-88.

Keys, H.J. R., S. S. Jacobs and D. Barnett. 1990. The calving and drift of iceberg B-9 in the Ross Sea, Antarctica. Antarct. Sci., 2(3), 243-257.

Koblents, Ya. P. 1965. Effect of the relief of Antarctic Shelf on the development of outlet glaciers. Sor. Antarct. Exped. Inf. Bull., 3, 5-9.

Lucchitta, B. K., K. F. Mullins, A. L. Allison and J. G. Ferrigno. 1993. Antarctic glacier-tongue velocities from Landsat images: first results. Ann. Glaciol., 17, 356-366.

Mawson, D. 1914. Australasian Antarctic Expedition, 1911-1914. Geogr. J., 44(3), 257-286.

Rott, H., P. Skvarca and T. Nagler. 1996. Rapid collapse of northern Larsen Ice Shelf, Antarctica. Science, 271 (5250), 788-792.

Shabtaie, S. and C. R. Bentley. 1982. Tabular icebergs: implications from geophysical studies of ice shelves. F. Glaciol., 28(100), 413-430.

Skvarca, P. 1994. Changes and surface features of the Larsen Ice Shelf, Antarctica, derived from Landsat and Kosmos mosaics. Ann. Glaciol., 20, 6-12.

Steed, R. H. N. and D. J. Drewry. 1982. Radio-echo sounding investigations of Wilkes Land, Antarctica. In Craddock, C., ed. Antartic geoscience. Madison, WI, University of Wisconsin Press, 969-975.

Swithinbank, C. 1988. Antarctica. U.S. Geol. Surv. Prof. Pap. 1386-B.

Swithinbank, C., P. McClain and P. Little. 1977. Drift tracks of Antarctic icebergs. Polar Rec., 18(116), 495-501.

Tchernia, P. and P. F. Jeannin. 1984. Circulation in Antarctic waters as revealed by iceberg tracks, 1972-1983. Polar Rec., 22(138), 263-269.

Vaughan, D. G. and C. S. M. Doake. 1996. Recent atmospheric warming and retreat of ice shelves on the Antarctic Peninsula. Nature, 379 (6563), 328-331.

Weller, G. 1993. The role of the Antarctic in global change; an international plan for a regional research programme. Cambridge, Scientific Committee on Antarctic Research (SCAR).

Wendler, G., K. Ahlnäs and C. S. Lingle. 1996. On the Mertz and Ninnis Glaciers, East Antarctica. 7. Glaciol., 42(142), 447-453. 